\title{
Investigation of the Relationship between the Organizational Cynicism Levels and Intent of Revenge of Sports Science Faculty Students Who Work
}

\author{
Sevim Güllü̈ ${ }^{1, *}$ \\ ${ }^{1}$ Faculty of Sport Sciences, Istanbul University-Cerrahpasa, Istanbul, Turkey \\ *Correspondence: Faculty of Sport Sciences, Istanbul University-Cerrahpasa, Istanbul, Turkey. E-mail: \\ sevim.gullu@istanbul.edu.tr
}

Received: November 5, 2018

Accepted: November 28, $2018 \quad$ Online Published: December 7, 2018

doi:10.5430/wje.v8n6p45

URL: https://doi.org/10.5430/wje.v8n6p45

\begin{abstract}
The research aims to determine the level of relationship between the organizational cynicism and the tendency of revenge of sports science students. In this study, descriptive and relational screening technique was used as the research technique. The working group consists of 105 students ( 36 female, 69 male). The participants are student who study at Istanbul University Faculty of Sports Science in the academic year of 2017-2018. All of the students have been working at an organization/ a workplace for at least 6 months. As the data collection tool, two scales were utilized with the personal information form prepared by the researchers. Organizational Cynicism Scale and Revenge Scale were used. The percentage (\%), frequency, skewness, kurtosis, t-test, ANOVA, Pearson Correlation analysis were used. As a result there is a positive relationship between the level of organizational cynicism and intention of revenge. It was revealed that gender and type of employment variables did not make a significant difference in organizational cynicism and sub-dimensions and will for revenge. However, significant differences have been identified in favor of the participants with a low salary in the behavioral sub-dimension of organizational cynicism. On the other hand, the scores of organizational cynicism and will for revenge of the participants are moderate and even low.
\end{abstract}

Keywords: organizational cynicism, revenge, negative behavior, counterproductive work behavior, student

\section{Introduction and Purpose}

The main purpose of the organizations is to maintain their existence, to increase efficiency and profit. Undoubtedly, the harmony between the individual and organization, the adoption of organizational culture and environment by members, the favorable health conditions of the organization and working quality have positive results for individuals and organizations. Also, if the horizontal and vertical communication channels are open and functional, and if there is an environment where the members of the organization are able to express themselves, to balance relationships between managers and their subordinates, the motivation increases, the positive behavior is encouraged while the tendency for negative diminishes.

Negative behavior can have short and long-term disruptive effects on both members and organizations. One of the most prominent results for organizations is the decrease of organizational commitment. In organizations, where negative organizational culture and climate is dominant and negative behavior are supported, the physical and mental health of members are also negatively affected. Considering the organization, the costs increase because of workforce decrease and there will be costs for the individual to bear as low quality of life.

In case of human resources demonstrate positive attitudes and behaviors; that would signify a competitive advantage for an organization. If human resources, who are the most important source of an organization, reflect negative attitudes and behavior, this is called the dark side of the organizational behavior. The dark side of the organizational behavior, defined as any act intentionally committed by the member or members of the organization for damaging others, self or the organization, is a significant phenomenon in terms of negative consequences and effects it may cause. While dealing with dark behavior that have many negative consequences such as a decrease in the organizational efficiency, increase in cost, damage of reputation and image, loss of customer; the establishment of an 
organizational culture that provides ethical behavior is highly critical (Binboğa et al., 2018: 383).

The fact that members are cynic (cynicism is a concept that is used in relation to members feeling hopeless and blocked and having negative emotions), have negative feelings and thoughts about the workplaces they work in, and occasionally revealing insults and critics about the organization and its members outside and inside the organization, may seriously damage the image of the organization. If rates of cynicism are high in the organization, it can be assumed that organizational commitment is very limited. Members with little sense of belonging to the organization will have a low tendency to show organizational citizenship behavior, while their tendency to leave the organization will be high. On the other hand, cynicism in the organization can also trigger the intentions of individuals to deliberately damage the organization and/or each other.

The person, who encounters a psychological or physical attack towards himself/herself strives to protect himself/herself instinctively. Particularly psychological attacks are frequently observed in professional life. A member, who thinks that $\mathrm{s} / \mathrm{he}$ is a victim of aggressive behavior can be expected to try to commit similar attacks to others, to behave unjustly toward others to protect himself/herself or worse, s/he may seek revenge. Revenge can be presented in many ways; slowdown, keeping some information secret, not giving the attacker the support needed for completing a duty, humiliating and embarrassing the attacker, backbiting the attacker, denouncing others, or using the attacker (Y1lmaz, 2014: 89,92).If the tendency to take revenge is not always realized, the environment and culture will be adversely affected if the members' tendency to damage is high. In the literature, the increase in counterproductive behavior at work, which are also referred to as organizational deviance, are undesirable.

According to Keashly (2001: 241), the negative behavior of the manager, member, and colleague in their relations with each other and in the organization are displayed in Table 1 (cited in Kiliç, 2013: 69,70).

Table 1. Negative Behavior Types Encountered in the Organization

Criticizing individuals (criticizing individuals about Criticizing the work (Making harsh, vulgar and destructive non-professional matters) comments about the work)

Shouting in anger

Making gestures

Taking revenge, retaliate (By complaining about the individual in the target or punishing him/her by revealing a special situation in which the individual will be put in a tough situation)

Spreading rumors, slandering

Revealing secrets (sharing special things that should not be said)

Deviate responsibility (Embracing responsibility when good results are obtained; blaming others when there are bad results)

Establishing unfair setup (directing the behavior of others according to his/her own will, cheating for the failure of the individuals)

Poor communication quality (not listening to individuals, not discussing with them, only getting information from others or information notes)

Showing off the authority in the unnecessary situations

Paying no attention (ignore the contributions of others or ignoring others, pretend not to know someone)
Swearing, giving nicknames

Threatening

"Others think the same way" (For hiding his/her own thoughts, pretending as conveying other individuals' thoughts)

Discrimination, unfairness

Unfair authority (deceiving individuals by pretending to have the authority)

Not giving support. Not caring, not providing encouragement or constructive feedback)

Using nonverbal communication and connotation (Indicating that $\mathrm{s} /$ he objects by using different methods such as body language, eye contact, breathing movements, remaining silent)

Refusing resources or opportunities (Not providing the information, materials or opportunities needed to complete a job)

Unreasonable expectations (To request something unusual or extremely difficult)

Cheating (diverting facts or thoughts, doing something behind the others' back)

(Keashly, 2001:242-245; cited in Kılıç, 2013:70) 
Organizations should identify the factors that cause negative behavior similar to those listed above, and take the required measures to avoid these behavior to be repeated. Such behavior cause material, psychological and social damages to the organization and its members (Köse and Aksu, 2013: 376) For example, as counterproductive behavior increase, production decreases while member dissatisfaction and psychological stress increase (Dunlop and Lee, 2004; Tepper, 2000).

\subsection{Organizational Cynicism}

Cynicism is a concept, caused by the member's belief that the organization lacks of integrity (Abraham, 2000:269; Naus et al., 2007; Johnson and O'Leary, 2003:629), developed by the hopelessness and frustration (Kalay et al., 2014:128). This signifies a negative behavior towards cognitive, affective and behavioral aspects of its organization (Yalçınkaya, 2014:109) and this is something undesirable in the workplace (Karacaoğlu ve Küçükköylü, 2015:401). Organizational cynicism is a concept used in relation to members' sense of hopelessness and disappointment and emphasizes more negative emotions. Conditions in the organization cause individuals to present cynical behavior. Cynic individuals are angry, hopeless, skeptical, suspicious, insecure, pessimistic, incredulous and certainly have a negative perspective. Consequently, behavior such as pickiness, constantly nitpicking and tendency to criticize are often encountered (Altınkurt et al., 2014: 26).

Cynicism is not a personality trait or an attitude of negative people. On the contrary, it is shaped and learned in the workplace environment. People do not decide to be cynical, at the end of their experience, they become cynic individuals (Yalçınkaya, 2014: 110). In other words, cynicism is not an innate personality trait, it is gained at the end of subsequent experiences (Çakıcı and Doğan, 2014: 80).

As can be assumed in the definition of organizational cynicism; extreme negative emotions based on skepticism and disappointment make members unhappy and severely disconnected from the work environment. Members consider that they cannot adapt the organizational values with their personal value judgments. Since the cynic member doesn't believe that the organizational integrity exists, s/he doesn't demonstrate prosocial behavior (Abraham, 2000:270).

Cynical individuals do not believe in the sincerity of the others and even reflect it to the opposite side with sarcastic and unkind words. They think that lying, abusing and pretending are the essential personality traits of the humans. These people often ask: "Why you are saying this? What's your purpose? Tell me your clear purpose, what are you trying to cover up? If you want to criticize someone, do it face to face" (Altınkurt et al, 2014:28).

In organizations with increased organizational cynicism, organizational policies begin to be perceived as inappropriate and incompetent, confidence in the future of the organization decreases and members cease using their self competencies for the success of the organization. If cynicism cannot be prevented in organizations, honest and respectful members, who contribute to the development of the organization are lost at the end (Doğan \& Uğurlu, 2014: 492). Following causes can be listed as the causes of organizational cynicism; perception of injustice in the organization, violation of psychological contract, the feeling of insecurity against the managers, deficiencies in the management style of managers and malpractices, excessive workload and mobbing (Çakıcı and Doğan, 2014: 80).

There are three dimensions of the organizational cynicism; believing that the organization lacks of integrity, feeling negative emotions towards the organization and at the end of these beliefs and feelings, the tendency to show critical behavior towards the organization (Dean et al., 1998:345);

- Cognitive dimension: This dimension consists of the belief that the practices in the organization lack of justice, sincerity and integrity (Altınkurt et al, 2014: 28; Kalay et al., 2014; Karacaoğlu and Küçükköylü, 2015: 403; Torun and Çetin, 2015: 138). They believe that managers do not have managerial skills and have pessimistic ideas about the organization (Torun and Çetin, 2015:138). The cynics believe that immoral behavior becomes the norm in the organizations (Karacaoğlu and Küçükköylü, 2015:403).

- Affective dimension: The emotional/affective dimension of organizational cynicism indicates that cynicism is something that is not only considered but is also felt (Karacaoğlu and Küçükköylü, 2015: 403). They have the following negative feelings towards the organization: shame, anger, fury, boredom and even disgust, disappointment and suspicion (Altınkurt et al., 2014:28; Kalay et al., 2014; Torun and Çetin, 2015:138). Individuals may feel sadness, hatred, and even shame when they think about the organization (Uzun and Ayik, 2016).

- Behavioral dimension: This dimension indicates a tendency to show humiliating and critical behavior towards the organization. It refers to the behavioral tendency toward negative attitudes and generally backbiting (Kalay et al., 2014; Karacaoğlu and Küçükköylü, 2015:403). Organizational cynics, criticizing 
the work of their colleagues, they exhibit negative behavior such as cynical gaze and chuckle (Altınkurt et al, 2014:28; Torun and Çetin, 2015:138).

In the literature, the relationship between the organizational cynicism and the following concepts is discussed: justice and commitment (Bernerth and Walker, 2007), perceived organizational support and performance (Byrne and Hochwarter, 2008), burnout (Özler and Atalay, 2011), member deviance (Evans et al, 2010), organizational commitment (Yıldız, 2013; Altınöz et al., 2011; Özgan et al., 2012), organizational justice (Efeoğlu and İplik, 2011), mobbing, organizational silence (Kalay et al., 2014), leader-member exchange (Kanbur and Kanbur, 2015), silence of the workers (Karacaoğlu and Küçükköylü, 2015 ), burnout and psychological contract violation (Üçok and Torun, 2014). In addition, at the end of research, the negative relationship between the perception of justice, perceived organizational support, loyalty, and leader-member exchange, while a positive relationship between the burnout, member deviance, mobbing, organizational silence, the silence of the workers and violation of psychological contract has proven to exist.

\subsection{Organizational Revenge}

Many studies have been conducted on the negative behavior in professional life and it has been concluded that these behavior are frequently encountered in culture and it cannot be considered as isolated event.

Therefore, these behaviors, with their predecessors and their results, have become a separate working area under the area for organizational behavior, as the dark side of the organizations (Tatarlar and Çangarl1, 2014).

Negative behavior observed in the workplace are examined in the literature under the following headings; revenge (Güllü and Şahin, 2016), counterproductive work behavior (Fox et al., 2007), organizational deviance (Berry et al., 2007), deviant behavior (Robinson and Bennett, 1995,) mobbing (Erdemir, 2012), retaliation (Skarlicki et al., 1997), workplace terror (Neuman and Baron, 1998), workplace violence (Rogers and Kelloway, 1997), organizational sabotage (Ambrose et al., 2002), antisocial behavior (Giacalone and Greenberg, 1997), workplace aggression (Hershcovis and Barling, 2010:25). In another study, dysfunctional work behavior were also examined (Van Fleet and Griffin, 2006: 698).

Deviant behavior undoubtedly affects the performance of organizations. Hence, it is necessary to develop and implement special methods to identify, control or eliminate deviant behavior before they become the new culture of the organization. It may be too late to reverse something at the final point (Appelbaum and Roy-Girard, 2007: 25).

One of the negative behaviors at work is the tendency for revenge. Revenge can be defined as the individual's desire to cause suffering or responding with other similar negative behavior when someone demonstrates a negative behavior (Nayir, 2016:4; Nayir, 2015:1208). Revenge behavior can be defined as any act that the other party does in order to harm the other party, to disrupt the peace of the other party and to punish the other party with the thought that the other party is damaging or goes wrong. Revenge behavior includes all aspects of aggressive behavior dimensions, such as oral, physical, indirect, direct, individual-oriented, explicit, hidden. However, aggression behavior are demonstrated only for one purpose (for revenge) (Doğan and Kılıç, 2014:109).

The presence of people who intend to take revenge on each other in organizations creates a severe threat to the organization. The person, who acts with strong negative emotions accompanying the intention of revenge cannot concentrate on his/her work and his/her efficiency will decrease because s/he will spend the time and energy on revenge. Hence, the performance of the organization decreases (Akın et al., 2012:80).

In the literature, there are some studies providing that the will for revenge has a positive relationship with impression management (Şener et al, 2017) and with the tendency to leave the work as well (Demir and Tütüncü, 2010: 72, 73). In addition, Ahmed et al. (2013) reported a positive relationship between organizational cynicism and organizational deviance. Lorinkova and Perry (2017) discovered a positive relationship between organizational cynicism and time theft. Moreover, Özer et al. (2014) have proved the existence of a relationship between the organizational cynicism and the will for revenge for the research assistants at a university.

Based on the literature information provided above, the basic hypothesis of this study was established as follows;

\section{There is a positive correlation between organizational cynicism and intent of revenge.}

The purpose of this study is determining the level of relationship between the organizational cynicism and the tendency of revenge of faculty of sports science students. 


\section{Materials and Method}

\subsection{Method of the Research}

In this study, descriptive and relational screening technique was used as the research technique.

\subsection{Working Group}

The working group consists of 105 students ( 36 female, 69 male) selected by convenience sampling methods, among the non-random sampling methods. The students study at Istanbul University Faculty of Sports Science in the academic year of 2017-2018, they are located in Istanbul. All of the students have been working at a workplace for at least 6 months.

\subsection{Data Collection Tool}

As the data collection tool, two scales were utilized with the personal information form prepared by the researchers.

- Organizational Cynicism Scale: Organizational Cynicism Scale, which was developed by Brandes et al. (1999), adapted to Turkish and validated by Karacaoğlu and İnce (2012) was used. The scale consists of three sub-dimensions. Cognitive sub-dimension consists of 5 statements, affective-sub-dimension consists of 4 statements while the behavioral sub-dimension consists of 4 statements. The likert-type rating scale was used in the scale as follows; "Strongly Agree" (5), "Agree" (4), "Neither agree nor disagree" (3), "Disagree" (2), "Strongly Disagree".

- Revenge Scale: Revenge Scale, which was developed by Stuckkless and Goranson (1992) and adopted to Turkish by Satıcı, Can and Akın (2015) and validated by them, was used. The scale is one-dimension. 1, 4, $5,8,9,11,15,17,18,20$ questions in the measurement tool reverse coded. The scale uses a likert scale type, ranging from " $1=$ I strongly disagree" to "7- I strongly agree".

\subsection{Analysis of Data}

SPSS 20 software was used in the statistical analysis of the obtained data. The percentage (\%) and frequency (f) values, which signify the descriptive statistical methods, were used to present personal information about the participants. Skewness and kurtosis values were taken into consideration when testing the normality of the data. The t-test was used for determining the differences between two-factor variables and the ANOVA test was used to determine the differences between three and more factor variables. In addition, Pearson Correlation analysis was used to determine the relationship between the participants' organizational cynicism and their sub-dimensions and their tendency to revenge. The significance level was accepted as $\mathrm{p}<0.05$.

\section{Findings}

Kaiser-Meyer Olkin (KMO) coefficient was calculated and Barlett Sphericity analysis was performed to test the suitability of the data for factor analysis. According to this; in the factor analysis for the Organizational Cynicism Scale, the result of the Kaiser-Meyer-Olkin Test (KMO) was found as 0.874 , indicating that the sample size was sufficient for factor analysis. Barlet Sphericity test results were also significant ( $x 2$ : 959,167; $p<0,05)$. In addition, for the Revenge Scale, the Kaiser-Meyer-Olkin Test (KMO) resulted in 0.880 and Barlet Sphericity tests resulted as follows $(\mathrm{x} 2: 1077.645 ; \mathrm{p}<0.05)$. These results are significant in terms of presenting that the analysis can be continued.

Table 2. Scale Score Values

\begin{tabular}{|c|c|c|c|c|c|c|c|}
\hline & $\mathrm{n}$ & Mean & Ss & Skewness & Kurtosis & $\begin{array}{l}\text { Cronbach Alpha } \\
\text { for the current } \\
\text { study }\end{array}$ & $\begin{array}{l}\text { Original Study's } \\
\text { Cronbach Alpha }\end{array}$ \\
\hline $\begin{array}{l}\text { ORGANIZATIONAL } \\
\text { CYNICISM SCALE }\end{array}$ & 13 & 2,55 & 0.831 & 0,633 & 0,671 & 0,910 & 0,910 \\
\hline Affective Sub-dimension & 4 & 2,12 & 0,993 & 1,026 & 0,873 & 0,820 & 0,940 \\
\hline Cognitive Sub-dimension & 5 & 2,63 & 0,963 & 0,361 & $-0,175$ & 0,906 & 0,870 \\
\hline Behavioral Sub-dimension & 4 & 3,02 & 0,894 & 0,060 & $-0,009$ & 0,718 & 0,820 \\
\hline REVENGE SCALE & 20 & 3,39 & 1,255 & 0,687 & 0,539 & 0.917 & 0,910 \\
\hline
\end{tabular}


When we look at the scale point values in Table 2, it is comprehended that the organizational cynicism levels of the participants examined within the scope of the research have an average value both in scale and sub-dimensions. While the highest mean was observed at the behavioral subscale and the lowest participation rate was found for the affective sub-dimension. On the other hand, the scores for the tendency to revenge are above average. When the reliability analysis is performed, it is understood that both the cynicism scale and its sub-dimensions and the revenge scale have a high Cronbach's alpha value, in other words, the reliability of the scales is considerably high. Tabachnick and Fidell (2007) consider the distribution as a normal distribution when the skewness and kurtosis values range between $+1,500$ and $-1,500$.

Table 3. Demographic Distribution of the Participants

\begin{tabular}{llcc}
\hline & & $\mathrm{n}$ & $\%$ \\
\hline \multirow{3}{*}{ GENDER } & Female & 36 & 34,3 \\
& Male & 69 & 65,7 \\
& Total & 105 & 100,0 \\
& 1000 TL and less & 30 & 28.6 \\
& between TL 1001-2000 & 44 & 41,9 \\
& over 2001 & 31 & 29.5 \\
& Total & 105 & 100,0 \\
& Permanent staff & 19 & 18,1 \\
& Contracted & 67 & 63.8 \\
& Part-time & 19 & 18.1 \\
& Total & 105 & 100,0 \\
\hline
\end{tabular}

According to Table 3, 36 (34.3\%) of the participants were female while 69 (65.7\%) of them were male. While 30 (28.6\%) earn a salary of $1000 \mathrm{TL}$ or less, $44(41,9 \%)$ of them earn a salary between 1001-2000 TL, and $31(29.5 \%)$ are paid over 2001. $19(18.1 \%)$ of the participants were employed as permanent staff while 67 of students $(63.8 \%)$ were contracted and $19(18.1 \%)$ were working part-time.

Table 4. Participation Rates to Organizational Cynicism and Sub-Dimensions and Revenge Rates, According to Salary Variable

\begin{tabular}{|c|c|c|c|c|c|c|c|c|}
\hline \multicolumn{2}{|c|}{ SALARY } & \multirow{2}{*}{$\frac{\mathrm{N}}{30}$} & \multirow{2}{*}{$\begin{array}{r}\text { Mean } \\
2,76\end{array}$} & \multirow{2}{*}{$\begin{array}{c}\mathrm{Sd} \\
, 827\end{array}$} & \multirow[t]{2}{*}{$\mathrm{df}$} & \multirow[t]{2}{*}{$\mathrm{F}$} & \multirow[t]{2}{*}{$\mathrm{p}$} & \multirow[t]{2}{*}{$\begin{array}{l}\text { Variance } \\
\text { group }\end{array}$} \\
\hline \multirow{4}{*}{$\begin{array}{l}\text { ORGANIZATIONAL } \\
\text { CYNICISM }\end{array}$} & $1000 \mathrm{TL}$ and less & & & & & & & \\
\hline & between TL 1001-2000 & 44 & 2,69 &, 800 & \multirow{3}{*}{2} & \multirow{3}{*}{2,902} & \multirow{3}{*}{0,059} & \\
\hline & over 2001 & 31 & 2,31 & 828 & & & & \\
\hline & Total & 105 & 2,59 &, 831 & & & & \\
\hline \multirow{4}{*}{$\begin{array}{l}\text { Affective } \\
\text { Sub-dimension }\end{array}$} & $1000 \mathrm{TL}$ and less & 30 & 2,42 & ,988 & \multirow{4}{*}{2} & \multirow{4}{*}{2,739} & \multirow{4}{*}{0,069} & \\
\hline & between TL 1001-2000 & 44 & 2,13 & 1,018 & & & & \\
\hline & over 2001 & 31 & 1,84 & ,906 & & & & \\
\hline & Total & 105 & 2,12 & ,993 & & & & \\
\hline \multirow{4}{*}{$\begin{array}{l}\text { Cognitive } \\
\text { Sub-dimension }\end{array}$} & $1000 \mathrm{TL}$ and less & 30 & 2,65 & 1,033 & \multirow{4}{*}{2} & \multirow{4}{*}{1,677} & \multirow{4}{*}{0,192} & \\
\hline & between TL 1001-2000 & 44 & 2,80 & 941 & & & & \\
\hline & over 2001 & 31 & 2,39 & ,904 & & & & \\
\hline & Total & 105 & 2,63 & ,963 & & & & \\
\hline \multirow{4}{*}{$\begin{array}{l}\text { Behavioral } \\
\text { Sub-dimension }\end{array}$} & $1000 \mathrm{TL}$ and less & 30 & 3,23 &, 765 & \multirow{4}{*}{2} & \multirow{4}{*}{3,705} & \multirow{4}{*}{$0,028 *$} & \multirow{4}{*}{$1>3$} \\
\hline & between TL 1001-2000 & 44 & 3,13 &, 853 & & & & \\
\hline & over 2001 & 31 & 2,68 & 982 & & & & \\
\hline & Total & 105 & 3,02 & 894 & & & & \\
\hline \multirow{4}{*}{$\begin{array}{l}\text { TENDENCY TO } \\
\text { REVENGE }\end{array}$} & $1000 \mathrm{TL}$ and less & 30 & 3,36 & 1,210 & \multirow{4}{*}{2} & \multirow{4}{*}{1,758} & \multirow{4}{*}{0,178} & \\
\hline & between TL 1001-2000 & 44 & 3,17 & 1,219 & & & & \\
\hline & over 2001 & 31 & 3,71 & 1,314 & & & & \\
\hline & Total & 105 & 3,39 & 1,255 & & & & \\
\hline
\end{tabular}


According to Table 4; at the end of the one-way analysis of variance (ANOVA), performed for determining whether there is a meaningful variance between the organizational cynicism of the participants and the means of revenge scale based on the salary criteria, it was revealed that the variance between the means of the group is statistically meaningful $(\mathrm{F}=3,705 ; \mathrm{p}=0,028)$. A complementary post-hoc analysis was performed to determine the sources of variances. The behavioral sub-dimension scores of those receiving a salary of less than $1000 \mathrm{TL}(3,23 \pm 0,765)$ were higher than the scores of those receiving a salary of over $2001(2,68 \pm 0,982)$.

Table 5. Participation Rates to Organizational Cynicism and Sub-dimensions and Revenge Rates, according to the Type of Employment

\begin{tabular}{|c|c|c|c|c|c|c|c|}
\hline \multicolumn{2}{|c|}{ TYPE OF EMPLOYMENT } & \multirow{2}{*}{$\begin{array}{l}\mathrm{N} \\
19\end{array}$} & \multirow{2}{*}{$\begin{array}{c}\text { Mean } \\
2,32\end{array}$} & \multirow{2}{*}{$\begin{array}{c}\mathrm{Sd} \\
, 626\end{array}$} & \multirow[t]{2}{*}{$\mathrm{df}$} & \multirow[t]{2}{*}{$\mathrm{F}$} & \multirow[t]{2}{*}{$\mathrm{p}$} \\
\hline \multirow{4}{*}{$\begin{array}{c}\text { ORGANIZATIONAL } \\
\text { CYNICISM }\end{array}$} & Permanent Staff & & & & & & \\
\hline & Contracted & 67 & 2,71 & ,908 & \multirow{3}{*}{2} & \multirow{4}{*}{2,02} & \multirow{3}{*}{0,138} \\
\hline & Part Time & 19 & 2,47 & 672 & & & \\
\hline & Total & 105 & 2,59 &, 831 & & & \\
\hline \multirow{4}{*}{$\begin{array}{c}\text { Affective } \\
\text { Sub-dimension }\end{array}$} & Permanent Staff & 19 & 1,70 & 672 & \multirow{4}{*}{2} & & \multirow{4}{*}{0,062} \\
\hline & Contracted & 67 & 2,28 & 1,074 & & \multirow{3}{*}{2,858} & \\
\hline & Part Time & 19 & 2,01 & 868 & & & \\
\hline & Total & 105 & 2,12 & ,993 & & & \\
\hline \multirow{4}{*}{$\begin{array}{c}\text { Cognitive } \\
\text { Sub-dimension }\end{array}$} & Permanent Staff & 19 & 2,46 &, 798 & \multirow{4}{*}{2} & \multirow{4}{*}{1,361} & \multirow{4}{*}{0,261} \\
\hline & Contracted & 67 & 2,75 & 1,019 & & & \\
\hline & Part Time & 19 & 2,40 & 897 & & & \\
\hline & Total & 105 & 2,63 & ,963 & & & \\
\hline \multirow{4}{*}{$\begin{array}{c}\text { Behavioral } \\
\text { Sub-dimension }\end{array}$} & Permanent Staff & 19 & 2,78 &, 869 & \multirow{4}{*}{2} & \multirow{4}{*}{1,063} & \multirow{4}{*}{0,349} \\
\hline & Contracted & 67 & 3,11 & ,922 & & & \\
\hline & Part Time & 19 & 3,00 & 808 & & & \\
\hline & Total & 105 & 3,02 &, 894 & & & \\
\hline \multirow{4}{*}{$\begin{array}{l}\text { TENDENCY TO } \\
\text { REVENGE }\end{array}$} & Permanent Staff & 19 & 3,65 & 1,011 & \multirow{4}{*}{2} & \multirow{4}{*}{1,687} & \multirow{4}{*}{0,190} \\
\hline & Contracted & 67 & 3,22 & 1,262 & & & \\
\hline & Part Time & 19 & 3,71 & 1,408 & & & \\
\hline & Total & 105 & 3,39 & 1,255 & & & \\
\hline
\end{tabular}

According to Table 5; at the end of the one-way analysis of variance (ANOVA), performed for determining whether there is a meaningful variance between the organizational cynicism of the participants and the means of revenge scale based on the type of employment, it was revealed that the variance between the means of the group is not statistically meaningful $(\mathrm{p}>0.05)$.

Table 6. Participation Rates to Organizational Cynicism and Sub-dimensions and Revenge Rates, According to the Gender Variable

\begin{tabular}{ccccccc}
\hline GENDER & & $\mathrm{N}$ & $\mathrm{Mean}$ & $\mathrm{Sd}$ & $\mathrm{t}$ & $\mathrm{p}$ \\
\hline \multirow{2}{*}{ ORGANIZATIONAL CYNICISM } & Female & 36 & 2,68 &, 818 & \multirow{2}{*}{0,714} & \multirow{2}{*}{0,477} \\
& Male & 69 & 2,55 &, 841 & & \\
\multirow{2}{*}{ Affective Sub-dimension } & Female & 36 & 2,35 & 1,075 & \multirow{2}{*}{, 698} & 0,098 \\
& Male & 69 & 2,00 &, 934 & & \\
\multirow{3}{*}{ Cognitive Sub-dimension } & Female & 36 & 2,67 &, 917 & 0,277 & 0,783 \\
& Male & 69 & 2,61 &, 993 & & \\
Behavioral Sub-dimension & Female & 36 & 3,01 &, 741 & $-0,82$ & 0,935 \\
& Male & 69 & 3,03 &, 969 & & \\
\multirow{2}{*}{ TENDENCY TO REVENGE } & Female & 36 & 3,13 & 1,018 & -1.514 & 0,102 \\
& Male & 69 & 3,52 & 1,350 & & \\
\hline
\end{tabular}

According to Table 6, there was no statistically meaningful variance between the mean scores of the organizational cynicism, sub-dimensions and revenge scores of the students who participated in the study, based on the gender variable, at the end of $\mathrm{t}$-test ( $\mathrm{p}>0.05$ ). However, female participants gave higher scores on the organizational 
cynicism scale while male participants gave higher scores on the revenge scale.

Table 7. Correlation Test Results of Organizational Cynicism Scale and Its sub-dimensions and Revenge Scale (Pearson Correlation)

\begin{tabular}{|c|c|c|c|c|c|c|}
\hline & & 1 & 2 & 3 & 4 & 5 \\
\hline 1-ORGANIZATIONAL & $\mathrm{r}$ & 1 & & & & \\
\hline CYNICISM & $\mathrm{p}$ & & & & & \\
\hline 2- Affective-Sub & $\mathrm{r}$ &, $864^{* *}$ & 1 & & & \\
\hline dimension & $\mathrm{p}$ & .000 & & & & \\
\hline 3- Cognitive & $\mathrm{r}$ &, $912^{* *}$ & $683^{* *}$ & 1 & & \\
\hline Sub-dimension & $\mathrm{p}$ & .000 & .000 & & & \\
\hline 4- Behavioral & $\mathrm{r}$ &, $835^{* *}$ &, $583^{* *}$ & $.650^{* *}$ & 1 & \\
\hline Sub-dimension & $\mathrm{p}$ & .000 & .000 & .000 & & \\
\hline 5- TENDENCY TO & $\mathrm{r}$ & $.294^{* *}$ & $218^{*}$ & $282^{* *}$ & $267^{* *}$ & 1 \\
\hline REVENGE & $\mathrm{p}$ &, 002 &, 025 &, 004 & ,006 & \\
\hline
\end{tabular}

In Table 7, according to the correlation analysis conducted to examine the relationship between the participants' organizational cynicism and sub-dimensions and the tendency of revenge, following results were obtained;

Positively low levels of organizational cynicism and revenge $(r=0.294, p<0.05)$; positively low levels of affective sub-dimension and revenge tendency $(\mathrm{r}=0.218, \mathrm{p}<0.05)$; positively low levels of cognitive sub-dimension and revenge tendency $(\mathrm{r}=0,282, \mathrm{p}<0,05)$; positively low levels of behavioral sub-dimension and revenge tendency $(\mathrm{r}=0,267, \mathrm{p}<0,05)$.

As a result, the main hypothesis is accepted.

\section{Discussion and Conclusion}

At the end of our study, it was revealed that gender and type of employment variables did not make a significant difference in organizational cynicism and sub-dimensions and will for revenge. However, significant differences have been identified in favor of the participants earning a low salary in the behavioral sub-dimension of organizational cynicism. Accordingly, those receiving a lower salary tend to criticize organizations/workplaces more than others and have a greater tendency to be cynical with their colleagues and humiliate them.

On the other hand, the scores of organizational cynicism and revenge intention of the participants are moderate and even low. It is considered that is related to the fact that the participants are very young, they are athletes in general and/or working in sports-related works. Since the sports bring people together and allow people to communicate, the behavior of the participants are positively affected. Participants continue their lives as a student both at the university and a professional for the rest of their times. Student life is thought to play a role in the low level of these scores. It is believed that as the socialization capabilities of the students are increased with the workplace and the school at the same time, the students are away from negative emotions and behavior. When the mean scores of the sub-dimensions were examined, it was determined that the behavioral sub-dimension mean was higher than the others. This can be interpreted that organizational cynicism reflects more behaviorally on individuals.

On the other hand, because the participants are students, they are fully aware that their current job is not their only option. Hence, they are relieved from pressure. The possibility of being employed in different sectors after graduation may also prevent them from developing obsessive and negative feelings about current jobs and workplaces.

In addition, it is considered that having content in the faculty emphasizing concepts such as sporting, fair play and olympics helps students to suppress their negative feelings. Although there is a positive relationship between the level of organizational cynicism and intention of revenge, the low level of this relationship is acknowledged as a positive result. When the level of relationship of the participants in the levels of organizational cynicism increases, the individuals' own interests will come into the prominence, and when the values such as honesty and justice will be eliminated, the low level of the relationship is considered as a positive result.

Tayfun and Çatır (2014) investigated organizational cynicism levels of nurses and found similar levels of organizational cynicism with our study. According to another study conducted with the participation of 305 teachers to determine the relationship between school principals 'perceptions of power and teachers' perceptions of 
organizational cynicism, the gender variable didn't change the cynicism perceptions, similarly to our study (Altınkurt vd, 2014:26). Kalay et al. (2014) also reported similar results. Organizational cynicism was low in a study conducted on 312 primary schools, which examined the relationship between ethical leadership behavior of managers and perceptions of organizational cynicism. This indicates that teachers' commitment to the organization at the primary school is high. On the other hand, similar to our study, perceptions of organizational cynicism do not differ according to gender variable (Doğan and Uğurlu, 2014:492). , Yıldırım et al. (2017) revealed that gender variable did not make a significant difference in organizational cynicism scores.

According to a study, conducted on 203 people working in Nevşehir Province Finance Corps, the effect of the silence of the members on organizational cynicism; the levels of organizational silence and organizational cynicism are weak. This is related to the fact that the research organization is a public institution and provides high employment security to its members and the participants are essentially educated people. According to the study, which examines the relationship between the teachers' perception of communication skills of teachers in Giresun and the level of cynicism of teachers; there was a low and negative relationship between communication skills and cynicism (Uzun and Ayık, 2016).

Kalay et al. (2014: 128) reported that almost $43 \%$ of the workforce in the United States had cynical attitudes in principle and that commitment in professional relations fell from 70\% to 15\% (Mirvis ve Kanter, 1991). These rates are really high. In addition, two negative issues such as organizational silence and mobbing have been positively related to organizational cynicism. Jhonson and O'Leary-Kelly (2003) reported that they have proved the existence of a relationship between cynicism and psychological contract violation. Abraham (2000) revealed that organizational cynicism is positively related to job dissatisfaction and alienation and negatively associated with organizational commitment and organizational citizenship behavior. Reichers, Wanous and Austin (1997) found organizational cynicism to be negatively related to job satisfaction and organizational commitment, and positively related to the filing of grievances. Andersson and Bateman (1997) showed that organizational cynicism is negatively related to intentions to engage in organizational citizenship behavior.

In addition, in our study, the gender variable did not lead to a statistically meaningful significant difference in intention to revenge. Nayir (2016) and Akın et al. (2012) ascertained that the gender variable did not make a meaningful difference in the intention of revenge of participants as in our study. According to a study examining 350 teacher candidates' perceptions of revenge, male teacher candidates intend to take more revenge compared to females. In addition, the teacher candidates adopt the revengeful behavior (Nayir, 2015:1214). On the other hand, according to Yllmaz's study (2014) in accommodation enterprises; male members' intention to revenge is more significant than female members. In addition, the intention of revenge of the members who have been exposed to aggressive behavior for more than 6 months is increasing. In other words, the members do not want to take revenge if they are exposed to short-term injustices or occasional injustices, but long-term victimization causes them to take revenge (Y1lmaz, 2014: 102). In a study conducted on university students, Satıc1 et al. (2015) revealed that men's revenge intentions were higher than women. Demirkasimoğlu (2018) in a study conducted on teachers, the tendency of revenge of the men was higher than the women's tendency.

In the organizational behavior literature, the concept of revenge is generally examined as the intention of revenge when an member encounters something unfair and engages in sabotage behavior (Tatarlar and Çangarlı, 2014). However, Güllü and Şahin (2017) did not find a relationship between organizational justice perceptions and revenge tendencies of physical education teachers. This was related to the fact that the sample group consisted of teachers that internalized fair play, which is a highly significant concept in sports.

Güllü and Şahin (2016) in their research on the revenge tendencies of coaches didn't reveal any significant difference in gender and type of employment (permanent, contracted) variables in revenge scale scores. According to a study conducted with 215 people, who investigated the mediating role of alienation in the effect of management style on counterproductive business behavior; it is ascertained that the democratic management style negatively affects the workers' counterproductive behavior and the alienation to their jobs (Kanten and Ülker, 2014: 34, 35).

Instead of the intention to take revenge in the organization, forgiveness can be considered as an essential form of behavior in terms of ensuring peace and avoiding conflict within the enterprise. The manager who forgives will lay a responsibility on someone by giving a second chance. It is anticipated that the establishment of the forgiveness culture within the organization will contribute to the increase of organizational commitment, sincere behavior in interpersonal relations and organizational performance. Thanks to the forgiveness culture, it is foreseen that the negative organization behavior such as cynicism, will for revenge decrease (Şener and Çetinkaya, 2015:36). 
Hence, it is necessary to take precautions to minimize the dark side of organizational behavior, which is caused by many factors (personal and situational factors), although it is impossible to be completely eliminating the dark side of organizational behavior. Because this has negative impacts such as the decrease of efficiency, the decrease of performance, the increase of costs, exhaustion, fall of job satisfaction and organizational commitment, which also damages the reputation of the organization and the members of the organization. In this context, in order to protect against the damages caused by such behavior, it is essential to establish an organizational culture with ethical values, to ensure the perception of organizational justice, to conduct integrity tests on personality, to establish a clear communication with the members, to critically approach the practices supporting such negative behavior and to be zero-tolerant against these behavior (Binboğa et al., 2018: 395).

As a result, there is a relationship between counterproductive behaviors and revenge intention. It is recommended to carry out this research in different organizations and working groups. Consequently, significant measures should be taken to minimize negative behavior in organizations.

\section{References}

Abraham, R. (2000). Organizational cynicism: Bases and consequences. Genetic, Social, and General Psychology Monographs, 126(3), 269-292.

Ahmed, W., Kiyani, A., \& Hashmi, S. (2013). The study on organizational cynicism, organizational injustice \& breach of psychological contract as the determinants of deviant work behavior. Actual Problems of Economics, 2(140), 145-154.

Akın, M., Özdevecioğlu, M., \& Ünlü, O. (2012). Örgütlerde intikam niyeti ve affetme eğiliminin çalışanların ruh sağlıkları ile ilişkisi. Amme İdaresi Dergisi, 45(1), 77-97.

Altınkurt, Y., Kürşad Y., Erol E., \& Salali E. T. (2014). Okul müdürlerinin kullandığı güç kaynaklarileöğretmenlerin örgütsel sinizm algıları arasındaki ilişki. Journal of Teacher Educationd and Educators, 3(1), 25-52.

Altinöz, M., Serdar, Ç. Ö. P., \& Siğindi, T. (2011). Algılanan örgütsel bağlllık ve örgütsel sinizm ilişkisi: Ankara'daki dört ve beş yıldızlı konaklama işletmeleri üzerine bir araştırma. Sosyal Ekonomik Araştırmalar Dergisi, 11(21), 285-316.

Ambrose, M, Seabright, M.A., \& Schminke, M. (2002). Sabotage in the workplace: the role of organizational injustice. Organizational Behavior And Human Decision Processes, 89(1), 947-965. https://doi.org/10.1016/S0749-5978(02)00037-7

Andersson, L. M., \& Bateman, T. S. (1997). Cynicism in the workplace: Some causes and effects. Journal of Organizational Behavior, $\quad 18, \quad 449-460$. https://doi.org/10.1002/(SICI)1099-1379(199709)18:5\%3C449::AID-JOB808\%3E3.0.CO;2-O

Appelbaum, S. H., \& Roy-Girard, D. (2007). Toxins in the workplace: affect on organizations and employees. Corporate Governance: The international journal of business in society, 7(1), 17-28. https://doi.org/10.1108/14720700710727087

Bernerth, J. B., Armenakis, A. A., Feild, H. S., \& Walker, H. J. (2007). Justice, cynicism, and commitment: A study of important organizational change variables. The Journal of Applied Behavioral Science, 43(3), 303-326. https://doi.org/10.1177/0021886306296602

Berry, C. M., Ones, D. S., \& Sackett, P. R. (2007). Interpersonal deviance, organizational deviance, and their common correlates: a review and meta-analysis. Journal of Applied Psychology, 92(2), 410. https://doi.org/10.1037/0021-9010.92.2.410

Binboğa, G., Eğin, E., \& Gülova, A. (2018). Örgütsel davranışın karanlık yüzü ve Türkçe literatürün incelenmesine yönelik bir araştırma. Finans Ekonomi ve Sosyal Araştırmalar Dergisi (FESA), 3(1), 382-399. https://doi.org/10.29106/fesa.364280

Brandes, P., Dharwadkar, R., \& Dean, J. W. (1999). Does organizational cynicism matter? Employee and supervisor perspectives on work outcomes. Eastern Academy of Management Proceedings, 150-153. Outstanding Empirical Paper Award.

Byrne, Z. S., \& Hochwarter, W. A. (2008). Perceived organizational support and performance: Relationships across levels of organizational cynicism. Journal of Managerial Psychology, 23(1), 54-72. 
https://doi.org/10.1108/02683940810849666

Çakıcı, A., \& Doğan, S. (2014). Örgütsel sinizmin iş performansına etkisi: meslek yüksekokullarında bir araştırma. Doğuş Üniversitesi Dergisi, 15(1), 79-89. https://doi.org/10.31671/dogus.2018.78

Dean Jr, J. W., Brandes, P., \& Dharwadkar, R. (1998). Organizational cynicism. Academy of Management review, 23(2), 341-352. https://doi.org/10.5465/amr.1998.533230

Demir, M., \& Tütüncü, Ö. (2010). Ağırlama işletmelerinde örgütsel sapma ile işten ayrılma eğilimi arasındaki ilişki. Anatolia: Turizm Araştırmaları Dergisi, 21(1), 64-74.

Demirkasımoğlu, N. (2018). The role of abusive supervision in predicting teachers' withdrawal and revenge responses / El papel de la supervisión abusiva en la predicción de las respuestas de venganza y abandono de los docents. Cultura y Educación, 30(4), 693-729. https://doi.org/10.1080/11356405.2018.1519904

Doğan, S., \& Uğurlu, C. T. (2014). Okul yöneticilerinin etik liderlik davranışları ile öğretmenlerin örgütsel sinizm algıları arasındaki ilişki. Gazi Üniversitesi Gazi Eğitim Fakültesi Dergisi, 34(3), 489-516.

Doğan, S., \& Kılıç, S. (2014). Üretkenlik karşıtı iş davranışlarının türleri, boyutları ve benzer kavramlarla ilişkilerine yönelik bir yazın incelemesi. Hacettepe University Journal of Economics \& Administrative Sciences/Hacettepe Üniversitesi Iktisadi ve Idari Bilimler Fakültesi Dergisi, 32(2), 103-132.

Dunlop, P. D., \& Lee, K. (2004). Workplace deviance, organizational citizenship behavior, and business unit performance: The bad apples do spoil the whole barrel. Journal of Organizational Behavior, 25, 67-80. https://doi.org/10.1002/job.243

Efeoğlu, İ.E., \& İplik, E. (2011), Algılanan Örgütsel Adaletin Örgütsel Sinizm Üzerindeki Etkilerini Belirlemeye Yönelik İlaç Sektöründe Bir Uygulama, Ç.Ü. Sosyal Bilimler Enstitüsü Dergisi, 20(3), 343-360.

Erdemir, B. (2012). Dünyada ve Türkiye'de yükseköğretimde psikolojik taciz (mobing) ve yasal mevzuat. Yüksekögretim Dergisi, 2(3), 151-158. https://doi:10.2399/yod.12.022

Evans, W. R., Goodman, J. M., \& Davis, W. D. (2010). The impact of perceived corporate citizenship on organizational cynicism, OCB, and employee deviance. Human Performance, 24(1), 79-97. https://doi.org/10.1080/08959285.2010.530632

Fox, S., Spector, P. E., Goh, A., \& Bruursema, K. (2007). Does your coworker know what you're doing? convergence of self-and peer-reports of counterproductive work behavior. International Journal Of Stress Management, 14(1), 41. https://doi.org/10.1037/1072-5245.14.1.41

Giacalone, R. A., \& Greenberg, J. (1997). Antisocial Behavior In Organizations. Thousand Oaks, Ca: Sage.

Güllü, S., \& Şahin, S. (2016). Antrenörlerin İntikam (Öç Alma) Davranışlarının Bazı Değişkenler Açısından İncelenmesi. Journal of International Social Research, 9(47), 863-871. https://doi.org/10.17719/jisr.2016.1432

Güllü, S., \& Şahin, S. (2017). Beden eğitimi ve spor öğretmenlerinin örgütsel adalet algısı ile örgütsel intikam (öç alma) eğilimi arasındaki ilişki. Journal of Human Sciences, 14(4), 3729-3741. https://doi.org/10.14687/jhs.v14i4.4776

Hershcovis, M. S., \& Barling, J. (2010). Towards a multi foci approach to workplace aggression: A meta analytic review of outcomes from different perpetrators. Journal of Organizational Behavior, 31(1), 24-44. https://doi.org/10.1002/job.621

Johnson, J. L., \& O’Leary-Kelly, A.M. (2003). The effects of psychological contract breach and organizational cynicism: not all social Exchange violations are created equal. Journal of Organizational Behavior, 24, 627-647. https://doi.org/10.1002/job.207

Kalay, F., Oğrak, A., \& Nişanc1, Z. N. (2014). Mobbing, örgütsel sessizlik ve örgütsel sinizm ilişkisi: Örnek bir uygulama. Kastamonu Üniversitesi İktisadi ve İdari Bilimler Fakültesi Dergisi, 4(2), 127-143.

Kanbur, A., \& Kanbur, E. (2015). Lider-üye etkileşiminin örgütsel sinizme etkisi: algılanan içsellik statüsünün aracilık rolü. Zeitschrift für die Welt der Türken/Journal of World of Turks, 7(2), 193-216.

Kanten, P., \& Ülker, F. (2014). Yönetim tarzının üretkenlik karşıtı iş davranışlarına etkisinde işe yabancılaşmanın aracılık rolü. Muğla Sitkı Koçman Üniversitesi Sosyal Bilimler Enstitüsü Dergisi, 32, 16-40.

Karacaoğlu, K., \& İnce F. (2012). Brandes, dharwadkar ve dean'in (1999) örgütsel sinizm ölçeği türkçe formunun geçerlilik ve güvenilirlik çalışması: kayseri organize sanayi bölgesi örneği. Business and Economics Research 
Journal.

Karacaoglu, K., \& Küçükköylü, C. (2015). Isgören Sessizliginin Örgütsel Sinizme Etkisi: Kamu Çalisanlari Üzerine Bir Arastirma/The Effect of Employee Silence on Organizational Cynicism: A Study on Public Employees. Ege Akademik Bakis, 15(3), 401-408

Keashly, L. (2001). Interpersonal and systemic aspects of emotional abuse at work: The target's perspective. Violence and Victims, 16(3), 233-268. https://doi.org/10.1891/0886-6708.16.3.233

Kılıç, S. (2013). Algılanan Örgütsel Etik İklim ile Üretkenlik Karşıtı İş Davranışları Arasındaki İlişkiler. Doktora Tezi. Niğde Üniversitesi, Sosyal Bilimler Enstitüsü, Niğde.

Köse, S. G., \& Aksu, A. (2013). Okullar için örgütsel sapma ölçeği. Nwsa-Education Sciences, 8(3), $375-389$.

Lorinkova, N. M., \& Perry, S. J. (2017). When is empowerment effective? The role of leader-leader exchange in empowering leadership, cynicism, and time theft. Journal of Management, 43(5), 1631-1654. https://doi.org/10.1177/0149206314560411

Mirvis, P. H., \& Kanter, D. L. (1991). Beyond demography: A psychographic profile of the workforce. Human Resource Management, 30(1), 45-68. https://doi.org/10.1002/hrm.3930300104

Naus, F., Van Iterson, A., \& Roe, R. (2007). Organizational cynicism: Extending the exit, voice, loyalty, and neglect model of employees' responses to adverse conditions in the workplace. Human Relations, 60(5), 683-718. https://doi.org/10.1177/0018726707079198

Nayir, K. F. (2015). Öğretmen adaylarının öç alma davranışına ilişkin görüşleri. International Periodical for the Languages, Literature and History of Turkish or Turkic, 10(11), 1205-1216. http://dx.doi.org/10.7827/TurkishStudies.8174

Nayir, K. F. (2016). Developing Organizational Revenge Scale and Examining Teachers' Opinions about Organizational Revenge. International online journal of educational sciences, 8(3). https://doi.org/10.15345/iojes.2016.03.012

Neuman, J. H., \& Baron, R. A. (1998). Workplace Violence and Workplace Aggression: Evidence Concerning Specific Forms, Potential Causes, And Preferred Targets, Journal Of Management, 24(3), 391-419. https://doi.org/10.1177/014920639802400305

Özer Ö., Sonğur C., Kar A., Top M., \& Erigüç G. (2014). Organizational stress, organizational cynicism, organizational revenge, intention to quit: a study on research assistant. The Macrotheme Review, 3(8), 121-128.

Özgan, H., Külekçi, E., \& Özkan, M. (2012). Öğretim elemanlarinin örgütsel sinizm ile örgütsel bağlilik düzeyleri arasindaki ilişkinin incelenmesi. International Online Journal of Educational Sciences, 4(1).

Özler, D. E., \& Atalay, C. G. (2011). A research to determine the relationship between organizational cynicism and burnout levels of employees in health sector. Business and Management Review, 1(4), 26-38.

Reichers, A. E., Wanous, J. P., \& Austin, J. T. (1997). Understanding and managing cynicism about organizational change. Academy of Management Executive, 11(1), 48-59.

Robinson, S. L., \& Bennett, R. J. (1995). A typology of deviant workplace behaviors: A multidimensional scaling study. Academy of Management Journal, 38(2), 555-572.

Rogers, K. A., \& Kelloway, E. K. (1997). Violence at work: personal and organizational outcomes. Journal Of Occupational Health Psychology, 2(1), 63. https://doi.org/10.1037/1076-8998.2.1.63

Satici, S. A., Can, G., \& Akin, A. (2015). İntikam Ölçeği: Türkçeye uyarlama çalışması. Anatolian Journal of Psychiatry/Anadolu Psikiyatri Dergisi, 16.

Şener, E., \& Çetinkaya, F. F. (2015). Bir liderlik özelliği olarak affetme ve örgütsel düzeyde etkileri üzerine bir inceleme. Işsletme Araştırmaları Dergisi, 7(4), 24-42.

Sener, E., Cetinkaya, F. F., \& Akkoca, Y. (2017). Hidden side of the employee relations: the relationship between impression management and revenge intention. International Journal of Business and Management Invention, $6(7), 73-84$

Skarlicki, Daniel P., \& Folger, Robert (1997). Retaliation in the workplace: the roles of distributive, procedural, and interactional justice, Journal Of Applied Psychology, 82(3), 434. https://doi.org/10.1037/0021-9010.82.3.434

Stuckless N., \& Goranson R. (1992). The revenge scale:Development of a measure of attitudes toward revenge. $J$ 
Soc Behav Pers., 7, 25-42.

Tabachnick, B. G., \& Fidell, L. S. (2007). Using multivariate statistics (5th ed.). Boston, MA: Allyn and Bacon.

Tatarlar, C., \& Güneri- Çangarlı, B. (2014). Madalyonun iki yüzü: örgütsel intikam davranışlarında yöneten ve yönetilen, 22. Ulusal Yönetim ve Organizasyon Kongresi, 22-24. Mayıs, Konya.

Tayfun, A., \& Çatır, O. (2014). Hemşirelerin örgütsel sinizm düzeylerinin incelenmesi. İşletme Araştırmaları Dergisi, 6(1), 347-365.

Tepper, B. J. (2000). Consequences of abusive supervision. Academy of Management Journal, 43, 178-190.

Torun, Y., \& Çetin, C. (2015). Örgütsel sinizmin kuşaklar bazında değerlendirilmesi: kuşaklara göre örgütsel sinizmin hedefinde ne var? Işs ve İnsan Dergisi, 2(2), 137-146. https://doi.org/10.18394/iid.83158

Üçok, D., \& Torun, A. (2014). Tükenmişliği Etkileyen Olumsuz Tutum Ve Beklentiler: Sinik Tutum Ve Psikolojik Sözleşme İhlali Algısı Üzerine Bir Araştırma. Ataturk University Journal of Economics \& Administrative Sciences, 28(1).

Uzun, T., \& Ayık, A. (2016). Okul müdürlerinin iletişim becerileri ile öğretmenlerin genel ve örgütsel sinizm tutumları arasındaki ilişkilerin incelenmesi. Mersin University Journal of the Faculty of Education, 12(2), 672-688.

Van Fleet, D. D., \& Griffin, R. W. (2006). Dysfunctional organization culture: The role of leadership in motivating dysfunctional work behaviors. Journal of Managerial Psychology, 21(8), 698-708. https://doi.org/10.1108/02683940610713244

Yalçınkaya, A. (2014). Türkiye'de örgütsel sinizm: 2007-2012 yılları arasındaki çalı̧̧malar üzerine bir değerlendirme. ISGUC The Journal of Industrial Relations and Human Resources, 16(3), 106-130. https://doi.org/10.4026/1303-2860.2014.0258.x

Yıldırım, U., Kolayiş, H., \& Aydın, B. (2017). Examination of organizational cynicism levels of provincial directorate of youth services and sports employees in terms of different variables. International refereed journal of humanities and academic sciences, Uluslararası Hakemli Beşeri ve Akademik Bilimler Dergisi, 35-55.

Yıldız, K. (2013). Örgütsel bağlllık ile örgütsel sinizm ve örgütsel muhalefet arasındaki ilişki. Electronic Turkish Studies, 8(6), 853-879. https://doi.org/10.7827/TurkishStudies.4544

Yılmaz, Ö. D. (2014). Algılanan mağduriyetin affetme eğilimi ve intikam niyeti üzerindeki etkisi: konaklama işletmeleri çalışanlarına yönelik bir araştırma. Afyon Kocatepe Üniversitesi İktisadi ve İdari Bilimler Fakültesi Dergisi, 16(1), 87-106. https://doi.org/10.5578/jeas.7489 